\title{
Correction to: Surface-enhanced Raman spectroscopy of blood serum based on gold nanoparticles for the diagnosis of the oral squamous cell carcinoma
}

Yingyun Tan ${ }^{1,2,3}$, Bing Yan ${ }^{4}$, Lili Xue ${ }^{5}, \mathrm{Yi} \mathrm{Li}^{6}$, Xianyang Luo ${ }^{4}$ and Ping Ji $\mathrm{j}^{1,2,3^{*}}$

\section{Correction to: Lipids in Health and Disease 2017 16:73 https://doi.org/10.1186/s12944-017-0465-y}

Following publication of the original article [1], the authors reported an error on the department of Funding in their paper. The Grant number of the National Science Foundation of China should be corrected from 81172578 to 81502584 .

\begin{abstract}
Author details
'Stomatological Hospital of Chongqing Medical University, Chongqing 400000, China. ${ }^{2}$ Chongqing Key Laboratory of Oral Diseases and Biomedical Sciences, Chongqing 400000, China. ${ }^{3}$ Chongqing Municipal Key Laboratory of Oral Biomedical Engineering of Higher Education, Chongqing 400000, China. ${ }^{4}$ Department of Otolarygology Head and Neck Surgery, the First Affiliated Hospital of Xiamen University, Xiamen 361000, China. ${ }^{5}$ Department of Stomatology, the First Affiliated Hospital of Xiamen University, Xiamen 361000, China. ${ }^{6}$ Department of Head and Neck Oncology, the West China Hospital of Stomatology, Sichuan University, Chengdu 610000, China.
\end{abstract}

Published online: 13 February 2019

\section{Reference}

1. Tan et al. Lipids in Health and Disease 2017 16:73. Surface-enhanced Raman spectroscopy of blood serum based on gold nanoparticles for the diagnosis of the oral squamous cell carcinoma. https://doi.org/10.1186/s12944-017-0465-y

\footnotetext{
*Correspondence: Pingjicq@163.com

'Stomatological Hospital of Chongqing Medical University, Chongqing 400000, China

${ }^{2}$ Chongqing Key Laboratory of Oral Diseases and Biomedical Sciences,

Chongqing 400000, China
}

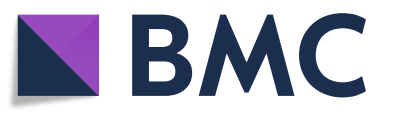

(c) The Author(s). 2019 Open Access This article is distributed under the terms of the Creative Commons Attribution 4.0 International License (http://creativecommons.org/licenses/by/4.0/), which permits unrestricted use, distribution, and reproduction in any medium, provided you give appropriate credit to the original author(s) and the source, provide a link to the Creative Commons license, and indicate if changes were made. The Creative Commons Public Domain Dedication waiver (http://creativecommons.org/publicdomain/zero/1.0/) applies to the data made available in this article, unless otherwise stated. 